\title{
Uncovering Job Satisfaction: The Role of Internal Marketing
}

\author{
Yessy Artanti \\ Universitas Negeri Surabaya \\ Surabaya, Indonesia \\ yessyartanti@unesa.ac.id
}

\author{
Andre Dwijanto Witjaksono \\ Universitas Negeri Surabaya \\ Surabaya, Indonesia \\ andredwijanto@unesa.ac.id
}

\author{
Widyastuti \\ Universitas Negeri Surabaya \\ Surabaya, Indonesia \\ widyastuti@unesa.ac.id
}

\begin{abstract}
In service-oriented companies, the function of internal marketing are to attract, retain, and motivate the quality of their employees by continuing to improve their ability to deliver services quality. Internal marketing focuses on effective internal organizational achievements and exchanges between organizations and employees as a prerequisite for successful external exchange. The internal marketing relevance to service operations lies in improving service quality in customer-oriented companies. This study seeks to examine the direct influence of internal marketing and corporate entrepreneurship on job satisfaction with organizational support as a moderator variable in the scope of Small and Medium Enterprises (SME's). The results of data analysis using Moderated Regression Analysis (MRA) on the owners and employees of SME's found that internal marketing and corporate entrepreneurship directly affect job satisfaction and moderated by organizational support
\end{abstract}

Keywords-internal marketing; corporate entrepreneurship; organizational support, job satisfaction

\section{INTRODUCTION}

The physical contact between the customer-seller in the service environment has continually grown and contributes significantly to the consumer's perception of service quality. However, there are few elements in service organizations that influence consumer perceptions of the interactions between members of the organization and its consumers [1]. Therefore, the exploration of the elements within the organization and its contribution in supporting the interaction of the employees (salespeople) and consumers continue to be done, for example about job design [2], organizational structure [3], interpersonal relationships, rewards, and resource allocation [4]. Activities in building internal relationships within the organization are often the main topics in the internal marketing and marketing literature.

Internal marketing becomes a critical issue in relationship marketing when the organization will carry out its marketing tasks [5]. Furthermore in its development, Berry [6] states that internal marketing is one of the relationship marketing strategies to consider in developing a long-term relationship plan with consumers and relevant to almost all organizations.
For a service company, for example, the quality of services sold will be determined by the skills and work attitude of the employees who produce the service.

Internal marketing is the best approach to build a serviceoriented organization. The internal marketing concept was first introduced by Berry [7] and Gronroos [8] as an approach that enabled and motivated all members of the organization to carry out responsibility and service-oriented. Internal marketing emphasizes that all members of the organization are consumers so that the organization strives to maintain and improve its relationships with its internal customers - that is, employees through quality internal services [9]. Nevertheless, there is a difference of perspective between the two and these differences have dominated the thinking in subsequent internal marketing.

Along with the development of subsequent researchers then also develop the elements of internal marketing. Some researchers mention internal marketing elements consisting of internal communication ([11]; [12]), training ([13]; [14]) and internal market research ([15]; [16]). These three elements were adopted in Huang [17] and Back et. al. [18] studies although substituted internal marketing research elements with perceived benefits. In contrast to previous studies, Back et. al. [18] argued that to be able to make employees able to deliver.

\section{LITERATURE REVIEW}

Some researchers have developed different internal marketing definitions and their contribution to various outcomes. Key ideas evolved such as the impact of internal marketing on employees (19]; [7]; [10]; [12], internal marketing impacts on organizations [21]; [19], internal marketing impact on satisfaction [20], and the impact of internal marketing on the development of cross-functional units within the organization [19][20].

Internal marketing is a strategy that aims to create highperforming individual values with respect to its indicators of reward systems, internal communications, training and development as well as senior leader support, to encourage larger performance employees and ultimately affect business performance [22]. The symbiotic relationship between an organization and an internal customer aimed at creating individual values that result in increased profitability, customer 
retention, market share, and organizational performance [23]. When organizations can meet their needs and wants and provide support to employees, they are more responsible and more focused on achieving their performance ([24]; [25]; [26]).

Most of studies found that internal marketing has a positive and significant effect on business performance ([22]; [26]). While the studies of [28][29] found the internal marketing had no significant effect on performance. The inconsistency of these findings indicates that internal marketing relations and organizational performance are still possible for further research. In addition to organizational performance, internal marketing is also predicted to play a role in improving employee work satisfaction in the organization [27]. It is well known that the primary purpose of internal marketing is to ensure that its employees feel that the leaders they work with care about them and their needs. Effective internal marketing implementation will positively affect employee attitudes including job satisfaction.

Hypothesis 1: Internal marketing has a significant effect on job satisfaction

Corporate entrepreneurship is a concept that deals with the entrepreneurial orientation within the organization's internal environment. Enterprise entrepreneurship is more than just developing new products, but also includes innovations in service, networking, and beyond. Enterprise entrepreneurship is crucial to organizational sustainability, development, profitability, and organizational renewal, especially in some large companies [34] as well as to stimulate innovation within organizations through exploring new opportunities, resources, and developing new products or services. The results of [35]; [36], [38] [30] conclude that corporate entrepreneurship / intrepreneurial behavior such as innovation, proactiveness, risk-taking are positively related to organizational performance. However, some studies argue that there is no significant influence between them [33] [39]. [46] and [47] propose four dimensions in corporate entrepreneurship, namely: innovation, risk taking, pro-activeness, and self-renewal. In addition, based on several research results, suggests that there is influence between corporate entrepreneurship (corporate entrepreneurship) on employee job satisfaction. Research conducted by [48] [31] [32] revealed that the entrepreneurship of the company produces work that can increase job satisfaction and strengthening entrepreneurial practices.

Hypothesis 2: The corporate entrepreneurship has a significant effect on job satisfaction

In this study, organizational support is measured by using several dimensions: (1) availability of resources, (2) support of organizational structure, and (3) rewards. Availability of resources (including time availability) is the availability of organizational resources to support the implementation of corporate entrepreneurship. Thus, employees should take advantage of the availability of resources for innovative activities [49][50][51]. New and innovative ideas can be developed if employees have available the time required. Organizations need to consider a rational distribution of work that enables employees to work with others in solving long-term problems. In the perspective of environmental entrepreneurship, employees are allowed to perform creatively and experiment as far as their working time [39] [52]. The availability of resources is intended to evaluate the workload, ensuring that employees have the time necessary to pursue and innovate and that their work is structured to support the achievement of short-term and long-term organizational goals [40]. According to Jong and Wennekers [41], the availability of resources is one of the important factors that can encourage corporate entrepreneurship.

A supportive organizational structure is an organizational structure designed to support the realization of entrepreneurial activity within the enterprise ([42]; [43]; [35], [44]). The results of [45] [53] show that there is a positive relationship between organizational structure that supports and innovation, and there is no relationship between supportive and proactive organizational structure.

Meanwhile, rewards and reinforcement are to motivate people to engage in innovative behavior ([44] and [46]). Companies provide rewards that are part of performance, challenge, improve responsibility and make people more innovative. According to Jong and Wennekers [41], the availability of rewards is an important factor that can drive the implementation of entrepreneurship / intrapreneurship because financial resources are needed to facilitate individuals in organizations to engage in innovation activities.

Hypothesis 3: Organizational support is able to moderate the influence of internal marketing on job satisfaction

Hypothesis 4: Organizational support is able to moderate the influence of corporate entrepreneurship on job satisfaction

\section{RESEARCH METHOD}

\section{A. Sample}

This research was conducted by using survey research design and questionnaire as its instrument. Questionnaires were distributed purposively sampling to employees who worked in several SME's in East Java in Indonesia. The method of collecting data by survey method is by distributing questionnaires to a number of respondents directly.

\section{B. Measurement of variables}

Internal marketing is measured by adopting instruments developed by several researchers, namely [47], [48], [49], [28], [50] consisting of dimensions, internal communication and training. Internal communication indicators: (a) two-way communication opportunities, (2) holding regular meetings for service quality, and (3) supervisors facilitating innovative ideas. While the training indicators: (a) provide training opportunities and (b) training to improve the quality of service and (c) the provision of information in the meeting forum.

Corporate Entrepreneurship is measured using the following dimensions: (1) Innovativeness (4 items), (2) Risk-taking (4 items), (3) Pro-activeness (4 items) adopted from [46] and (4) Self-renewal (3 items) were adopted from [47].

Organizational support is measured using instruments from [39] consisting of six items. 
Job Satisfaction is measured by adopting Hornsby et. al.[40] research, which comprises internal satisfaction instruments and external satisfaction. Internal satisfaction refers to causes that create job satisfaction or in other words satisfaction is achieved through the work itself, including: feelings of achievement, growth, self-adoration, independence, and feeling control. While external satisfaction is not directly related to the work itself includes a good work environment, welfare, high salaries, promotions, and others. Each statement is measured using a Likert scale of 5 points intervals (strongly disagree $=1$ to strongly agree $=5$ ).

\section{Model Development and Data Analysis}

Based on the above description and analysis of various models, that in addition to adopting the model used by [41], this study also uses some of the models used by [1]; [42]; and [43] and produced the research models on figure 1:

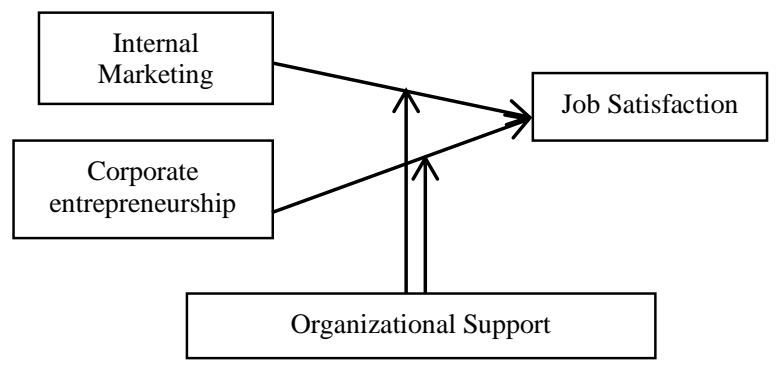

Figure 1. Research Model

Based on the figure of research problems, the measurement of research variables and the development of research models used model equation Moderated Regression Analysis (MRA):

\section{RESUlTS AND DisCUSSION}

The validity test results show that all items are valid statements because they have values greater than 0.361 and reliable with cronbach alpha value> 0.70 . Thus, it can be concluded that all items of revelation for all variables declared reliable and can be used as a measuring tool. Based on the distribution of questionnaires on the owners and employees of SME's can be obtained data that most respondents are female, aged 31-40 years and work less than 1 (one) year.

This study is analyzed using Moderated Regression Analysis (MRA). Based on data analysis got result as table I.

TABLE I. RESULT OF MODERATED REGRESSION ANALYSIS

\begin{tabular}{|c|r|r|r|r|r|}
\hline \multirow{2}{*}{ Model } & \multicolumn{2}{|c|}{$\begin{array}{c}\text { Unstandardized } \\
\text { Coefficients }\end{array}$} & $\begin{array}{c}\text { Standardized } \\
\text { Coefficients }\end{array}$ & \multirow{2}{*}{ t } & \multirow{2}{*}{ Sig. } \\
\cline { 2 - 4 } & \multicolumn{1}{|c|}{$B$} & Std. Error & \multicolumn{1}{c|}{ Beta } & & \\
\hline (Constant) & $-92,254$ & 40,787 & & $-2,262$ &, 026 \\
$\mathrm{X} 1 \rightarrow \mathrm{Y}$ & 2,648 & 1,409 & 1,478 & 1,880 &, 064 \\
$\mathrm{X} 2 \rightarrow \mathrm{Y}$ & 1,176 &, 496 & 1,786 & 2,370 &, 020 \\
$\mathrm{X} 1 \mathrm{XVM} \rightarrow \mathrm{Y}$ &,- 104 &, 060 & $-2,465$ & $-1,730$ &, 087 \\
$\mathrm{X} 2 \mathrm{XVM} \rightarrow \mathrm{Y}$ &,- 046 &, 021 & $-2,965$ & $-2,167$ &, 033 \\
& & & & & \\
\hline
\end{tabular}

Using a significance level of 5\%, the explanation of each hypothesis based on table I are as follows: (1) Hypothesis 1 which states that the internal marketing has a significant effect on job satisfaction is rejected. This can be seen from the significance value of 0.064 above the sig $5 \%$, (2) hypothesis 2, which states that the corporate entrepreneurship has a significant effect on job satisfaction, is accepted. This can be seen from the significance value of 0.020 below the $5 \%$ sig value, (3) hypothesis 3, which states that organizational support is able to moderate the influence of internal marketing on job satisfaction, is rejected. This can be seen from the significance value of 0.087 above the $5 \%$ sig value, and (4) hypothesis 4, which states that organizational support is able to moderate the influence of corporate entrepreneurship on job satisfaction, is accepted. This can be seen from the significance value of 0.033 below the $5 \%$ sig value.

Based on some of the above explanations about organizational support and internal marketing, these two concepts actually have the same meaning, that is how should treat employees so that employees are satisfied and committed both to the work and organization. Viewed from an internal marketing perspective, it focuses on achieving effective internal exchange between organizations and employee groups as a prerequisite for successful exchanges in external markets. This can improve the effectiveness and efficiency of an internal marketing program as one of the ideas in relationship marketing [6]. Internal marketing is one of the relationship marketing strategies to consider in creating a long-term relationship plan with consumers [6] [54]. Internal marketing treats employees as internal customers, which is the process of establishing individual values within the organization to meet their needs and wants, so that employee performance increases and eventually organizational goals are achieved.

Based on some previous research explained that internal marketing is proven to contribute to some outcomes from employees as internal customers as well as for external customers that is final consumers. However, this study found the opposite results of most of the previous research results. Based on the results of data analysis stated that the internal marketing does not give a significant effect on job satisfaction. Internal marketing as measured by internal communication and training dimensions does not contribute to job satisfaction perceived by its employees. It can be understood that the object of this research is the employees of SMEs that are mostly small scale. The activities in the internal marketing indicators are not fully implemented by SME's. This can be seen from regular meetings, facilitating innovative ideas, training procurement and information on training that has not been implemented by SME's due to the limited knowledge, skills and education of SME's owners.

The company's entrepreneurship is measured by using item samples i.e the company tries new ideas, emphasizes product development, expenditures for product innovation and fully experiments gives a significant effect on job satisfaction. In this study, the employees of SME's have experienced the development of new ideas given by SME's and this impact on job satisfaction perceived by employees.

When viewed from the theory of organizational support, the power of Perceived Organizational Support (POS) depends on the attributes that exist on employees based on some activities that have been done company, such as training. Furthermore, the idea of POS can be viewed from the social exchange process 
where employees feel given the trust to help the organization in achieving its goals and expect to get rewards from their efforts. On the other hand, POS can also be viewed as one way to meet socio emotional. These forms of organizational support are growing. Hornsby et. al. [44] mentions that the form of organizational support can start from material things (extrinsic) such as allowances, bonuses, salaries, etc. Then, it is until nonintrinsic, praise, attention, acceptance, familiarity, information, self-development, and so on.

In this review, the understanding of organizational support is brought to the marketing concept of how an internal marketing strategy can come about with full support from the organization. In the context of human resources, the nature of organizational support views employees as individuals who must be supported both material and non-material, but in the context of internal marketing, employees are treated as internal customers in addition to external customers -- consumers who must meet their needs and wants-- so employee performance increases and eventually organizational goals are achieved.

The perceived organizational support is inseparable from the role of leadership, human resource practices, and working conditions and workplace justice expected by employees. Organizational support is inseparable from the leadership role of the organization. Top management must be responsive to the needs of employees so that they have high performance. A good relationship between an employee and a leader as a representative of an organization is one form of organizational support implementation as well as contained within the context of internal marketing. Implementing an internal marketing program requires ongoing management support to be more effective. When employees perceive leader behaviors that drive their efforts to perform better, employees will do so with high motivation in achieving their organizational vision.

In this study, perceived organizational support is measured by indicators that SME's contribute to employees, SME's consider aspirations to employees, SME's consider the values that employees have, and SME's are proud of the achievements of the employees it turns out to provide a significant impact on satisfaction felt its employees.

It should be noted that there is a clear link between indicators on organizational support and internal marketing. Internal marketing is a strategy that aims to create highperforming individual values with respect to its indicators of reward systems, internal communications, training and development as well as senior leader support, to encourage larger performance employees and ultimately affect business performance in a positive way [22] [56]. Individuals or employees will be motivated to perform better when they feel the benefits of their training, needs and desires are met as well as the behavior of leaders who support their work. Therefore, employees need to be given knowledge about organizational vision and mission, training and development, reward and communication system.

It is because there is still a link between internal marketing and organizational support that leads to the hypothesis that organizational support moderates internal marketing relationships against job satisfaction is rejected or unsupported. Organizational support will be debilitating or even destructive if this organizational support interacts with internal marketing. This could also be because both of these concepts have a relationship between one another and it will not give effect if they are interacted.

Corporate entrepreneurship is a concept that deals with the entrepreneurial orientation within the organization's internal environment. Enterprise entrepreneurship is more than just developing new products, but also includes innovations in service, networking, and beyond. Enterprise entrepreneurship is crucial to organizational sustainability, development, profitability, and organizational renewal, especially in some large companies [34] as well as to stimulate innovation within organizations through exploring new opportunities, resources, and developing new products or services. The results of [35]; [36], [37]; [38] ; [55] conclude that corporate entrepreneurship / intrepreneurial behavior such as innovation, proactiveness, risk-taking are positively related to organizational performance.

In this study, the hypothesis stating that organizational support moderate the entrepreneurship relationship of the company to job satisfaction is accepted or supported. The influence of corporate entrepreneurship on job satisfaction perceived by employees would be more powerful with the existence of organizational support. The interaction between internal marketing and organizational support makes a more significant contribution when compared to each of these variables independently as independent variables.

\section{MANAGERIAL IMPLICATIONS}

Communication is the process of conveying information, understanding from one person to another. Communication is an important factor in an organization, because every member and subsystem within the organization or company is expected to establish communication with various elements in the organization to achieve corporate objectives. Relationships among members of the organization is brought together through communication in order to form togetherness and make the organization run according to its function. Communication within the organization aims to improve individual performance and ultimately improve organizational performance. Internal communication is a means to share information and knowledge among employees, so that they will be able to do their work.

Internal communication that runs within an organization is in order to establish a good relationship between employees with employees, employees with leadership and between various subsystems. Through the internal communication program is expected that employees always feel cared for and appreciated so as to create a sense of ownership, motivation, creativity and a sense of achievement to work with as much as possible and impact on job satisfaction. Measuring the success of employee performance is not only the implementation of his work, but also on aspects of internal employee communication skills within the organization. Thus, communication between employees and various parts of subsystems within the organization is part of the implementation of internal marketing that can affect employee behavior and performance.

The importance of employee training to improve the profitability of the company because satisfied and trained 
employees will be more satisfied work and better able to apply the quality of good service to satisfy customers. Training and development for employees is their need to improve their skills and ability to do their work. Training and development is important for employees to perform better and as an effort to create their responsibilities in the future. Training and development are all efforts aimed at improving the performance of employees in certain occupations for which they are responsible, or work related to their work. The objectives that must be fulfilled from this training program are increasing individual performance, increasing job satisfaction, and finally increasing organization performance. Employee training and development are the overall activities to improve, as well as develop employee behavior (eg, knowledge, skills, productivity, job competence, attitudes, discipline, and work ethic) in order to achieve the desired goals individually or organizational goals. With training and development, employees are able to work on, improve, and develop their work.

\section{LIMITATIONS AND FURTHER RESEARCH IMPLICATION}

The majority of these respondents are employees who work less than one year. This ultimately allows respondents to assess internal marketing, organizational support, corporate entrepreneurship, and less than optimal job satisfaction. In addition, the level of job satisfaction perceived by employees can vary depending on the duration of their work. The selection of respondents for future research is expected to be employees who have a working period of more than five years. It is expected that adequate working period will be better able to perceive the condition of the company better. In addition, the limitations in this study are the lack of matching indicators selected on internal marketing variables so as to cause unsupported several hypotheses. The future research should further adjust the indicator of variable measurement with the condition of the research object.

\section{REFERENCES}

[1] S. J. Bell, B. Mengüç, and S.L Stefani, "When Customers Disappoint: A Model of Relational Internal Marketing and Customer Complaints," Journal of the Academy of Marketing Science., 32(2), 112-116. 2004.

[2] J. M. George, "Salesperson Mood at Work: Implication for Helping Customers," Journal of Personal Selling \& Sales Management 18 (Summer)., pp. 23-30, 1998.

[3] J. Conduit, and T. M. Felix, "How Critical Is Internal Customer Orientation to Market Orientation?," Journal of Business Research., 51 (January), pp. 11-24, 2001.

[4] E. W. Morrison, "Organizational Citizenship Behaviors as a Critical Link Between HRM Practices and Service Quality," Human Resources Management., pp. 493-512. 1996.

[5] C. Gronroos, "Relationship Marketing: The Strategy Continuum," Journal of the Academy of Marketing Science., vol. 23 No. 4, pp. 252-5, 1990.

[6] L. L. Berry, "Relationship Marketing of Services-Perspectives from 1983 and 2000," Journal of Relationship Marketing., vol. 1, No. 1, pp. 59-70, 2002.

[7] L. L. Berry, "The Employee as Customer," Journal Retail Banking., Vol. 3, No.1: pp. 25-28, 1981.

[8] C. Gronroos, "Toward a third phase in service quality research: challenges and future directions,"Advances in Services Marketing and Management., vol. 2, pp. 49-64, 1993.

[9] C. Gronroos, "Internal marketing - an integral part of marketing theory," in Donnelly, J.H. and George, W.E. (Eds), Marketing of Services, American Marketing Association Proceedings Series, pp. 236-238, 1981.
[10] M. Rafiq, and P. K. Ahmed, "The scope of internal marketing: Defining the boundary between marketing and human resource management," Journal of Marketing Management., vol. 9(3), pp.219-232, 1993.

[11] P. Naude, J.Desai, and J.Murphy, "Identifying The Determinants Of Internal Marketing Orientation," European Journal of Marketing., vol. 37, No.9, pp.1205, 2003

[12] R. Varey, and B. Lewis, "A broadened conception of internal marketing," European Journal of Marketing., vol.33, No.9/10, pp. 926944, 1999.

[13] B. J. Gray, "Benchmarking Services Branding Practices," Journal of Marketing Management., vol 22(7/8), pp.717-758, 2006.

[14] L. A. Zampetakis, and V. Moustakis, "Fostering corporate entrepreeurship through internal marketing - Implications for change in the public sector," European Journal Innovation., vol.10(4), pp.21. 2007.

[15] A. Paraskevas, "Internal Service Encounters in Hotels: An Empirical Study," International Journal of Contemporary Hospitality Management., vol.13(6), pp.285-29, 2001.

[16] P. G. Quester, and A. Kelly, "Internal Marketing Practices in the Australian Financial Sector: An Exploratory Study," Journal of Applied Management Studies., vol.8(2), pp.21, 1999.

[17] Y. T. Huang, and S. Rundle-Thiele, Exploring Internal Marketing Measurement, Working paper., Griffith University, 2013.

[18] K. J. Back, C. K. Lee, and J. Abbott, "Internal Relationship Marketing: Korean Casino Employee Job Satisfaction and Organisation Commitment," Cornell Hospitality Quarterly, 52(2), 111-124, 2011.

[19] D. Ballantyne, "A relationship-mediated theory of internal marketing," European Journal of Marketing., vol.37, No.9, pp.1242 - 1260. 2003.

[20] M. Rafiq, and R. M. Ahmad, "Advances in Internal Marketing: Definition, Synthesis and Extension." Journal of Services Marketing, 14(6), 449-462, 2000.

[21] Ahmed, P.K., Rafiq, M. and N. M. Saad, "Internal marketing and the mediating role of organizational competencies", European Journal of Marketing., vol.37 No. 9, pp.1221-41, 2003.

[22] P. K. Ahmed, and M. Rafiq, "Internal Marketing Issues and Challenges. European Journal of Marketing., vol.37(9), pp.1177-1186, 2003.

[23] H. F. Lewis, and S. K. Mazvancheryl, "A model for efficiency analysis of the customer satisfaction process," Innovative Marketing., vol.7(1), pp 33-45, 2011.

[24] E. Gummesson, "Lip service - a neglected area in service marketing," Journal of Services Marketing , 1(1), pp. 19-24. 1987.

[25] P. Tansuhaj, D. Randall, and J. McCullough, "Applying the internal marketing concept within large organizations: as applied to a Credit Union," Journal of Professional Services marketing., vol.6 (2), pp.193202, 1991.

[26] S. B. Keller, D.F. Lynch, A. E. Ellinger, a n d J.Ozment, "The Impact of internal Marketing Efforts In Distribution Service Operations", Journal of Business Logistics, vol.27(1), pp.109, 2006.

[27] N. Bouranta, G.Mavridoglou, and P.Kyriazopoulos. "The Impact of Internal Marketing to Market Orientation Concept and their Effects to Bank Performance," Operational Research. An International Journal; vol.5, no.2, pp.349-362, 2005.

[28] S. Zahra, "Corporate entrepreneurship and financial performance: The case of management leverage buyouts." Journal of Business Venturing, 10: 225-247, 1995.

[29] S. Zahra, "Predictors and financial outcomes of corporate entrepreneurship: An exploratory study", Journal of Business Venturing, 6: 259-285, 1991.

[30] S. Zahra and D. Garvis, "International corporate entrepreneurship and firm performance: The moderating effect of international environmental hostility," Journal of Business Venturing, 15(5-6): 469-492, 2000.

[31] G. T. Lumpkin and G. D. Gregory, "Clarifying The Entrepreneurial Orientation Construct and Linking It to Performance," The Academy of Management Review., vol. 21, no.1, pp. 135-172. 1996.

[32] B. Antoncic, and O. Zorn, "The Mediating Role of Corporate Entrepreneurship in the Organizational Support-Performance Relationship: An Empirical Examination," Managing Global 
Transitions., University of Primorska, Faculty of Management Koper, vol. 2(1), pp 5-14, 2004.

[33] J. Wiklund, and D. Shepherd, "Entrepreneurial orientation and small business performance: a configurational approach," Journal of Business Venturing., Vol. 20, (1), pp.71-91, 2005.

[34] B. Aktan and C. Bulut, "Financial Performance Impacts of Corporate Entrepreneurship in Emerging Markets: A Case of Turkey," European Journal of Economics, Finance and Administrative Sciences., Vol. 12, pp. 69-79. 2008.

[35] L Lekmat, and C Selvarajah, "Corporate entrepreneurship and firm performance: An empirical study in auto parts manufacturing firms in Thailand," Proceedings of The 2nd International Colloquium on Business and Management., 2008.

[36] J. S. Hornsby, and D. F. Kuratko, "The influence of entrepreneurial environment on job satisfaction, reinforcement practices and behaviors," Paper presented at the United States Association for Small Business and Entrepreneurship., Hilton Head, S.C. 2003.

[37] T. K. Das, and B. Teng, "Time and entrepreneurial risk behavior," Entrepreneurship Theory and Practice., Vol. 22 (2), pp. 69- 88, 1997.

[38] P. S. Dennis, and G. C. Jeffrey, "Strategy Formation Patterns, Performance, and the Significance of Context," Journal of Management., Vol. 23 (2), pp.189-209.

[39] M. J. Scheepers, J. Hough, and J. Z. Bloom, "The development of an instrument to assess the enacted environment for corporate entrepreneurship in South Africa," Management Dynamics., vol.17(4), pp.2-17, 2008.

[40] J. Hornsby, D. T. Holt, D. F. Kuratko, “The Dynamic Nature Of Corporate Entrepreneurship," Assessing The CEAI. Academy of Management Annual Meeting Proceedings 2008(1):1-6, 2008. Retrived from DOI: 10.5465/AMBPP.2008.3371654.

[41] J. de Jong \& S. Wennekers, "Intrapreneurship; Conceptualizing entrepreneurial employee behaviour," Scales Research Reports H200802, EIM Business and Policy Research, 2008.

[42] W. Guth, and A. Ginsberg, "Guest Editors' Introduction: Corporate Entrepreneurship," Strategic Management Journal., vol.11, pp. 5-15, 1990. Retrieved from http://www.jstor.org/stable/2486666.

[43] G. C. Jeffrey and D. P. Slevin, "A Conceptual Model of Entrepreneurship as Firm Behavior,” Entrepreneurship Theory and Practice., vol.16(1), pp. $7-26,1991$.

[44] J. Hornsby, and \& D. F. Kuratko, and S. A. Zahra, "Middle Managers' Perception of the Internal Environment for Corporate Entrepreneurship: Assessing a Measurement Scale," Journal of Business Venturing. 17(3). 253-273, 2002. Retrieved from doi: 10.1016/S0883-9026(00)00059-8

[45] J. Hough, and R. Scheepers, "Creating corporate entrepreneurship through strategic leadership," Journal of Global Strategic Management, 03, pp.17-25, June, 2008.

[46] C. M. Lau, and \& H. Y. Ngo, "The HR system, organizational culture, and product innovation," International Business Review., Elsevier, vol. 13(6), pp.685-703, December. 2004.

[47] A. Caruana, and P. Calleya, "The Effect of Internal Marketing on Organizational Commitment among Retail Bank Managers," International Journal of Bank Marketing. vol.16, pp.108-116, 1998. retrieved from http://dx.doi.org/10.1108/02652329810213510

[48] M. T. Ewing, and A. Caruana, "An internal marketing approach to public sector management: The marketing and human resources interface, International Journal of Public Sector Management, 12(1), pp.17-29, 1999. https://doi.org/10.1108/09513559910262652

[49] P. Naudé, J. Desai, and \& J. Murphy, "Identifying the determinants of internal marketing orientation,"European Journal of Marketing. 37(9). 1205-1220, 2003. Retrieved from doi:10.1108/0390560310486951

[50] Y. M. Shiu, and T. W. Yu, (2010) "Internal marketing, organisational culture, job satisfaction, and organisational performance in non-life insurance," The Service Industries Journal., vol.30(6), pp.793-809, 2010. Retrieved from DOI: 10.1080/02642060701849840

[51] P. Paille, L. Bourdeau, and I. Galois, (2010), "Support, trust, Satisfaction, Intent to Leave, and Citizenship at Organizational Level," International Journal of Organizational Analyzis, 18(1), 41-58, 2010.
[52] S. C. Chang, M. S. Lee, "A study on relationship among leadership, organizational culture, the operation of learning organization and employees' job satisfaction," The Learning Organization, vol.14(2), $\begin{array}{lll}\text { pp.155-185, 2007. Retrieved from https://doi.org } & \end{array}$ /10.1108/09696470710727014

[53] Y. T. Huang, S. Rundle-Thiele, "A holistic management tool for measuring internal marketing activities, Journal of Services Marketing, 29 (6/7), pp.571-584, 2015. Retrieved from https://doi.org/10.1108/JSM03-2015-0112

[54] J. A. W. Huang, R. H. Weng, C. S. Lai, and J. San-Hu, (2012). "Perceptual Market Orientation Gap and Its Impact on Relationship Quality and Patient Loyalty: The Role of Internal Marketing," Evaluation and The Health Professions. vol.36 92., pp. 204-227, 2012.

[55] Y. T. Huang, and S. Rundle-Thiele, Exploring Internal Marketing Measurement, Working paper, Griffith University. 2013.

[56] M. L. Kraimer, S. J. Wayne, and R. A. Jaworski, "Sources of support and expatriate performance: the mediating role of expatriate adjustment," Personnel Psychology 54: 71-99, 2001. 